Discourse and Communication for Sustainable Education, vol. 11, no. 2, pp. 33-44, 2020

\title{
The World in Children's Minds - or Sustainable Entrepreneurship Education as Empowerment to Shape a Desirable Future
}

\author{
Kerstin Schmidt-Hönig and Gerlinde Pröbstl \\ University Teacher College, Vienna/Krems, Austria
}

\begin{abstract}
How can we succeed in meeting the challenges of the future world in the best possible way? In order to support children in their development into optimistic, self-effective adults, it is necessary to find out how children perceive their world and how they combine these perceptions with their cognitive knowledge. This article examines the question of what children's ideas about the world look like in children at the end of primary school, or what information is included in them. In a pilot study, mental maps were used to visualize the child's world view. Accompanying questions were used to ascertain the children's knowledge of current global problems. The focus was on the students' thematic interests, which accompanied the discussions with the pupils. Already the first evaluations of the Mental Maps, which were made by the students, allow conclusions to be drawn. There is no uniform level in the children's cognitive maps with regards to the concrete positional relationship of spatial units, e.g. continents and oceans. The statements about the content details of these maps are shaped by the children's perception. The Mental Maps show a combination of indirect, direct and emotional spatial perception. The awareness of the pupils regarding global challenges, oriented towards the Sustainable Development Goals, proves to be clearly pronounced in the impulse-based interviews in the $4^{\text {th }}$ grade. Thus, the pilot study allows the conclusion that already at the end of primary school pupils develop an awareness of global challenges and the ability to act. The SDGs of the UN Agenda 2030 offer a suitable basis for this. In addition to the development of a worldwide rough topographical orientation grid, the aim is to give children an understanding of global connections and to educate them to become global citizens of the future world.
\end{abstract}

Key words: concepts of space, mental maps, space-related competence of action, social entrepreneurship education (SEE), sustainable development goals.

\section{Introduction}

"The social process in which today's schoolchildren grow up is marked by a far greater and more radical change in ways of thinking, lifestyles and social practices than by evolutionary change. School must also prepare for this - also by encouraging a fulfilled 
present and a desirable future" (Stoltenberg, 2013, p. 13; Fedosejava et al., 2018). This means that we have to enable our children to solve the "problems of the world" as adults by familiarising them with them already in primary school.

This article will deal with the following questions:

1. What global challenges can be identified by fourth grade pupils and what solutions do they propose?

2. How are children's spatial concepts developed?

3. What role do mental maps play as a method of visualisation in the development of children's world-views?

\section{Consciousness of the Challenges in the World of the $21^{\text {st }}$ Century}

The advancing globalisation, increasing mobility of people and goods and a rapidly growing flood of information are changing the lives and experiences of children and young people at an increasing rate. This is a challenge for society as a whole and schools can make a significant contribution to meeting this challenge by contributing to a "fulfilled present and encouraging a desirable future"(Stoltenberg, 2013, p. 13). Insights into the interrelationships and interactions between the natural environment and human activities enable children at primary school level to develop targeted action competence. This requires that subject-specific working methods, e.g. reading and decoding maps, and content that is subjectively perceived by children as being close to life, are brought into connection.

The direct sphere of experience of children is often limited, so that spaces can only be experienced indirectly. In this context, "above all information, assessments and explanations from third parties, e.g. other people, the school or the media, play a decisive role" (Schmeinck, 2013, p. 9). It is usually not possible for children to recognise whether these are subjective or objective representations of individual facts or systemic contexts. For primary school pupils, as a rule, the trust in an objective representation by third parties predominates.

Spatial and historical basic assumptions form the basis for children and young people to develop insights into the connections and interactions between natural conditions and human activities. This insight requires already at primary school level a targeted, age-appropriate "promotion of a critical-reflective approach to spatial perception (Schmeinck, 2013, p. 9).

A didactic approach that is oriented towards the living environment and the future contributes to the linking of content that is subjectively significant for the children and geographical working methods by the use of suitable materials and methods that are oriented towards learning goals. The rapidly progressing development in the field of digital media has also changed the living environment of primary school pupils, so that today the development of traditional (map) competences (Lenz, 2006) is also in primary school supported and extended by the use of digital tools (digital maps, digital globe, GIS).

In addition to developing a well-founded spatial orientation competence, it is also important to support children in reflecting on their subjective perception of space. Only when children recognise spaces as changeable, usable and representable, they are able to take responsibility for the preservation and care of spaces in the sense of sustainable development and in the sense of action orientation (Salite, 2015). 
In the context of teaching, the ideal of the objective map (Gryl, 2010) often predominates and subjective perception of space is not taken into account. However, it is the subjective construction process which, by linking it with previous knowledge and experience, makes it possible to establish socio-economically determined and spatially related connections to identify options for action. According to Vielhaber, world views are "the result of a permanent confrontation of the subject with his environment, filtered through ideologies, inclinations and prejudices, nourished by knowledge and experience (Vielhaber, 2000, p. 46).

\section{Development of Childhood Spatial Concepts}

The assumption that the perception of the external world and the cognitive representational ability of the external world form the basis of human behaviour (Weichhart, 2008, p. 162) explains the preoccupation of different research directions with this innate characteristic of humans. The biological-psychological approach is based on the assumption that human beings order their environment by means of perception and thus make it possible for them to orient themselves in this environment. The geography of perception places the subjective perception of space in the context of objectively existing spaces.

The development of perception appears to be particularly significant for children and adolescents, especially since these changes significantly due to the expansion of the radius of action caused by socialisation. The brain's individually different reactions to natural and social stimuli can be made visible in different areas of the brain by means of imaging techniques. Since different spatially relevant information is perceived in spatial perception, the hippocampus, the cerebellum and, for information of an emotional nature, the limbic system are involved. These findings of neurobiological research are of great importance in the context of sustainable learning. The linking of indirect, direct and emotional perceptions leads to the construction of sustainable memory content, which can be visualized in the form of mental maps.

The perception of space and the notion of space depend strongly on the age of the researcher. The subjectively constructed spatial concepts clearly show the individually developed ability to imagine space, but also personal spatial experiences, attitudes and values (Kestler, 2002).

From a developmental psychological point of view, the child's perception of a space changes from an egocentric perception, which is strongly focused on details, to an overall view in adulthood. In contrast to the traditional idea of Piaget (Kaminske, 2012, p. 12), more recent research assumes that children and adolescents already develop overall perceptions of spaces. The investigation of cognitive maps, mental maps, allows the conclusion that spatial concepts are developed independently due to ontogenetic development and are naturally present (Kaminske, 2013, p. 5). In order to promote action competence and participation for future societies, it is important for the learning process of children and adolescents to take the following premises into account when creating and interpreting Mental Maps:

- The known is perceived more consciously than the unknown;

- Unknown things are incomplete or poorly represented due to the lack of primary experience;

- The increasing spatial distance to one's own location reduces the structural accuracy of the room or the significance of the process (Kaminske, 2013, p. 5). 
The insights gained in a series of experiments by Kaminske (2013) appear to be of great relevance against the background of a globally oriented concept of space and a society based on unlimited information and communication.

Students thus construct their subjective world view under very different conditions. In the classroom, these children and young people are often confronted with a world view presented as "objective" and thus made insecure. The current didactics, based on a moderate constructivist learning theory, show possibilities to integrate mental maps of pupils at all school levels into the subject lessons (primary level) or the geography lessons (secondary level).

Possible sub(teaching/learning) objectives are:

- Promotion of the ability to imagine and orientation;

- Awareness of your own subjective mental map;

- Further development of the personal, consciously reflected idea of space;

- Supplementing incomplete spatial concepts with objective information;

- Respecting the Mental Maps of other people;

- Recognition of the influence of the media on subjective spatial perception.

By achieving these goals, the geography of perception makes a significant contribution to sustainable development in various areas. It enables the promotion of a regional consciousness enriched with relevant factual information, but also the correction of clichés and stereotypes. Even pupils at primary school level can thus develop competence in action. Already at this level, this enables a respectful interaction with nature and mankind and a global perspective in the satisfaction of individual needs and future use of space in the sense of global citizenship (Weixelbaumer, 2001).

Schäfer understands spatial orientation as the ability "to detect points in space in their position relative to each other, to their own location and to a point of orientation lying outside of one's own person, in terms of absolute or relative distance and direction" (Schäfer, 1984, p. 181). Direct orientation in space thus refers to locations and situational relationships in known and familiar experiential spaces. Indirect orientation in as yet unknown spaces is very important in today's living environment, since the predominantly medial mediation of spaces requires to a high degree the capacity of mental orientation.

Children perceive and imagine spaces long before they enter primary school. When entering elementary school, children's map images are characterised by a rather egocentric world view, whereby order, distances, scale or orientation are not usually taken into account. It is only in the course of primary schooling that learners develop a feeling for perspectives as well as assessments of distances. A complex spatial conception of different spaces is usually only achieved by children towards the end of primary school (Ribeiro, 2013, p. 23).

Schniotalle (2003), on the basis of her study on students' perceptions of Europe, presents three levels of development that are passed through in the construction of the idea of space. She takes up the stage theory according to Stückrath (1968), the theory of spatial thinking in children according to Piaget and Inhelder (1975), the theory of spatial perception according to Hart and Moore (1973), as well as the theory of spatial perception according to Engelhardt (1977) and critically relates them to the challenges of the present day.

At the first level of development, the child is in an egocentric orientation system. The idea of space is determined by some individual elements that are important for the child. The second level of development is characterised by a progressive objectification 
of spatial perception, whereby the child begins to orient itself to fixed points in its environment and pre-forms of perspective are recognisable. It is only at the third level of development that the world as an organized whole is formed. The relationship between the perception of spaces and actions in these spaces is balanced at this level. In describing these levels, Schniotalle deliberately refrains from clearly defining the individual levels and assigning age groups (Schniotalle, 2003, p. 43). Orientation in rooms on the third level is considered challenging and a process of lifelong learning.

The following diagram shows the great importance of extra-curricular factors influencing spatial conceptions, especially as a result of globalisation, tourism and media consumption (Schniotalle, 2003, p. 80).

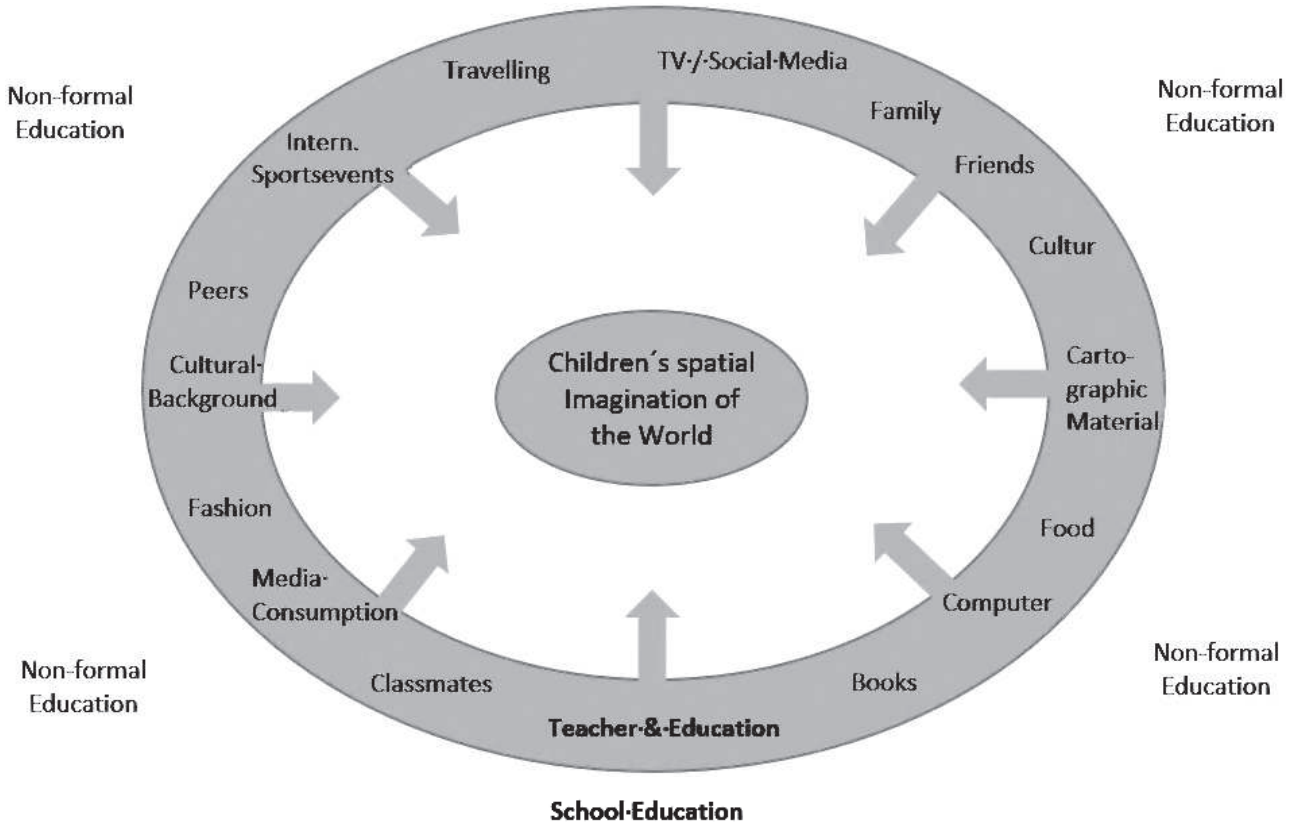

Figure 1. Factors influencing children's spatial perception of the world

\section{Use of Mental Maps as a Visualization Method}

Mind Maps, Concept Maps, Mental Maps, Global Maps - all forms stand for maps in the mind. A delimitation can only be vaguely defined, for example, the term mind map stands for "thought maps" (Bönsch, 2012, p. 89), concept maps are understood as “conceptual maps" (Behrendt \& Reiska, 2001, p. 9), mental maps show ideas about geographical areas (Adamina, 2014, p. 85) and global maps are maps that "track down and openly reveal questions of globalisation and the contents of global learning" (Schwarz, 2010, p. 16).

According to Ziervogel (2011) mental maps are graphic representations of their own perceptions of familiar spaces (neighbourhoods, routine routes, etc.), since individuals face the daily task of orienting themselves in space. They reflect the subjective interpretation of objective socio-spatial facts and serve as a source of information, on the basis of which in-depth spatially relevant data is collected. The method of Mental Maps is based 
on cognitive and behavioural science research into the relationship between perceived environmental information and personality traits (Dangschat \& Kogler, 2019, p. 1340) and is mainly used in geographic learning. Schniotalle (2003), Schmeinck (2007) and Adamina (2008), for example, investigated "student perceptions of natural geographic phenomena, spatial orientation, spaces near and far, and lifestyles of people in other parts of the world". In addition to the mind-map-like presentations, the children note down keywords or explain their mental map in a short interview. Mental maps are also used as a form of presentation for pupils (Adamina, 2014, p. 85). "Teaching details means creating confusion. To establish the relationship among things means to convey knowledge” (Montessori, 1997, p. 126).

\section{Pilot Study on Children's Ideas about the World}

This contribution focuses on the initial results of a pilot study on the socio-spatial ideas of fourth-grade pupils and their view of the challenges facing the world. In the summer semester 2019, a didactic practical research was conducted in the context of a course under the direction of Kerstin Schmidt-Hönig. In this seminar, students were to analyse and interpret professionally relevant situations and cases according to scientific criteria and to participate in a concrete research project. The intention was to enable students to observe, evaluate and further develop their future professional activities with the help of research methods and strategies. The aim was also to enable students to deepen their basic knowledge of research methodology and to understand research as a constant challenge for their further education. They should be in a position to receive current research in their future field of work and to use scientific methods to address issues relevant to their careers and to society (Curriculum, 2019, p. 260).

In addition, the students of the $6^{\text {th }}$ semester were to be given an insight into the life and imaginary world of the children of a fourth grade through concrete practical research. The Sustainable Development Goals of the UN Agenda 2030 were chosen as the thematic focus for the practical research. The examination of the personal geographical world view as well as the 17 goals at the student level formed the basis for the subsequent pilot study. The students were thus confronted with central aspects of global challenges in a self-reflective manner before working on these topics with students from the fourth grade. The aim was on the one hand to gain specialist knowledge and on the other hand to build up an awareness of global social challenges. In preparation for the pilot study, the students created an interview guide in the seminar and selected impulse pictures that fit the 17 global goals of sustainability.

Key questions of the pilot study were: Which mental maps of the world do pupils have at the end of primary school? Which global social challenges are the pupils aware of and which ideas for their solution do they find?

\section{Research Design}

The pilot study followed a qualitative approach to capture children's mental images of the physical world on the one hand and their awareness of global challenges on the other. In the first part of the study, 50 students in the fourth grade of the Praxisvolksschule were asked to draw a world map according to their ideas and then to describe them orally. One student was assigned to each child. The conversations during the drawing and the 
description of the mental map were recorded. The students also asked guiding questions to ascertain how the children construct their ideas of the world.

In a second part, the pupils were asked impulse questions on selected aspects of the SDGs. These questions were supported by impulse pictures. The key question interviews made it possible to set thematic impulses for a free narrative of the children, but also to structure the course of the interview. Since the leading questions were developed by the students on the basis of their personal thematic interests, the leading questions and impulse pictures differed in part and were supplemented by closed questions.

The survey took place on two mornings, with 25 students from each class being interviewed. Between the two dates, the students were able to review and refine their research methodology. After conducting the mental map survey and the interviews, the mobile phone conversations were transcribed according to Mayring (2010). The material collected by the students was edited under the guidance of the seminar leader using Mayring's guidelines for summary qualitative content analysis. In the course of paraphrasing and generalising the students' statements, person-specific and comparable complexes of statements could thus be obtained. The mental maps produced by the children were analysed according to the 15 categories of Schmeinck (2007). These range from an impossible classification of what is drawn to a detailed representation of the world in the form of continents. In addition, the individual classifications distinguish between the way in which the outlines of different countries are represented, their arrangement and their labeling. The results are first insights into the imaginary world of children.
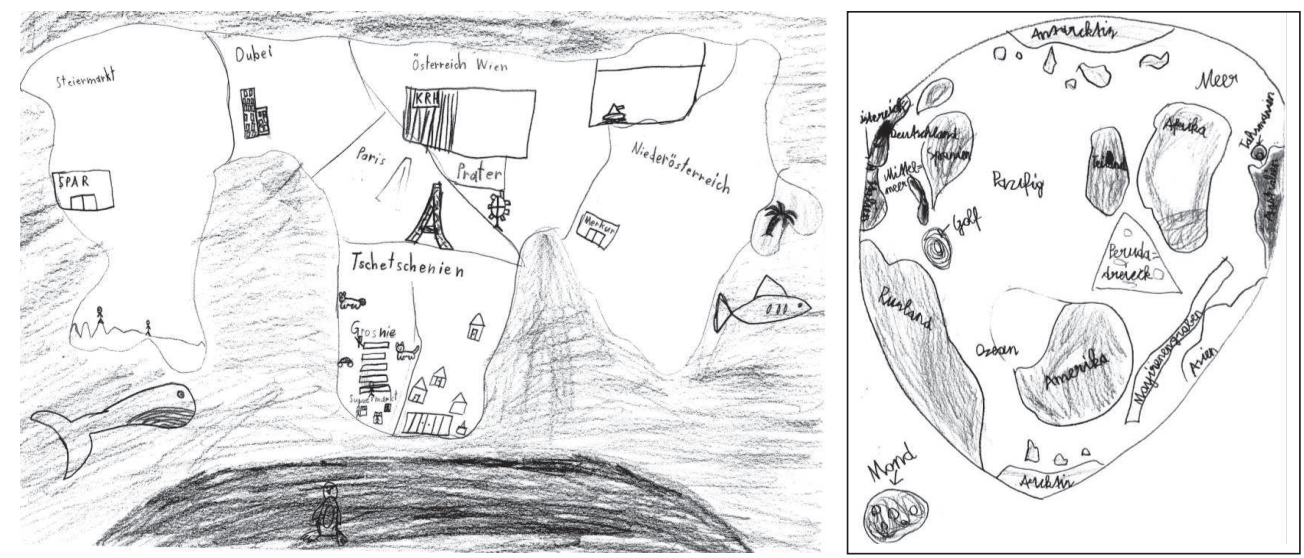

Figure 2. Mental Maps: Fatima, 9 years old, and David, 9 years old

\section{Research Results}

The evaluation of the Mental Maps of children at the end of primary school shows a wide range of ideas about the world. Most of the drawings can be clearly classified, only occasionally mixed forms occur. Overall, the Mental Maps reflect all categories according to Schmeinck (2007), thus confirming the assumption that there is no uniform level of children's cognitive maps. Above all, the depiction of fictional, digital worlds clearly shows that the spatial imagination is very divergent and decisively influenced by the children's individual life world. The majority of children can recognize and draw 
individual areas of land. The pupils know that countries are spatially closed off from others, but the situational relationships are not ensured and the distribution of countries is arbitrary. The children distinguish between water and land areas and can to a large extent label the countries or continents they have drawn.

The selection of the countries drawn and also their labels allow the conclusion that the existing subjective spatial concepts are shaped by personal and travel experiences. Fatima (9 years old) draws in her map countries and federal states that have a family connection (Austria/Vienna, Lower Austria, Styria, Chechnya) as well as countries (cities) where she was on holiday (Dubai, Paris). The shopping possibilities in the different places of residence and also the activities, e.g. hiking are important aspects for Fatima. The drawn animals in Grozny suggest pets (possibly at the grandparents'), which Fatima cannot have in Vienna. Fatima's Mental Map shows the connection of the indirect, direct and emotional perception of space, which according to Kestler (2002) leads to the construction of sustainable mental images of space. The premises of Kestler (2012), according to which the known is perceived more consciously than the unknown and the unknown is not represented, can be confirmed by the example of this Mental Map. Surprisingly, however, some Mental Maps also include major sporting events (football, Olympics) and information from current news coverage.

The results of the subsequent verbal description of the Mental Maps by the children show that the pupils know far more countries by name and can also express attributions than they have drawn. The reactions to the impulse questions also show the necessity of verbalising the Mental Maps. The students whose Mental Maps correspond most clearly to a physical world map state that they have their knowledge of the world from books or from map posters in their children's room. For example the mental map of David (9 years) shows a clear differentiation between continents and oceans. Only Austria, Germany, Italy, Spain and Thailand are mentioned as countries. Thailand can be assumed as a holiday destination, but there is no clear statement about where David knows the European countries from. Very striking is the non-Europe-centred representation of the world. David says that he got his knowledge from books. It is obvious that his primary interest concentrates on the oceans. This is confirmed by the drawing of the Gulf, the Bermuda Triangle and the Mariana Trench. David's Mental Map is representative of the scientific approach of primary school pupils. This is an opportunity to promote the ability to act and the development of self-efficacy of children by placing the emphasis on a respectful interaction between man and nature as early as the primary school level. The ability of each individual to act appears to be particularly important in view of current social change, economic challenges and ecological changes (Pröbstl \& Schmidt-Hönig, 2020, p. 51). Weixelbaumer (2001) emphasizes in this context the importance of a global perspective in the sense of global citizenship.

But to what extent are students aware of global challenges?

In the second part of the pilot study, the pupils were shown questions and pictures on the Global Goals of the UN Agenda 2030. More than half of the children named environmental pollution, especially the pollution of the seas through plastic, wars, poverty and hunger as the main problems of the world. Around ten percent of children recognize flight, unemployment/child labour, food waste, medical care and poor infrastructure as global problems. When asked how they know about this, the students answered mainly with "from class", followed by "parents and relatives" and "television". The conclusion is that the children are only to some extent able to build up connections and can use 
possible background knowledge very limited for justifications. When asked how these problems could be reduced, the pupils respond with the following examples:

... using electric cars.

... stop throwing garbage in the ocean.

... paper bags instead of plastic bags.

... buy and distribute food for the poor.

... not buying fruit in winter.

... shops should only sell what is growing in our country.

... like Ghandi-using words to get people away from war.

... the government has to change things.
... take a bag to go shopping.

... collect and recycle garbage.

... stop using plastic.

... donate leftover food.

Finally, the children were asked what they would need to be happy. The majority answered with "family" followed by "material goods" such as (bed, toys, books, ...). "food", "medicine" and "a home". Only one child at a time mentioned "friends", "money" as important for feeling good.

The evaluation of the statements on the impulse pictures of the individual Global Goals shows that pupils of a fourth school level are already aware of essential problems of the world, the solution of which is aimed at in the Global Goals. The children's suggestions for solutions reveal starting points that are reflected in the description of the 17 goals. These range from measures to be taken personally to the demand for more communication and measures at government level.

A possible connection between the mental maps of the children and their awareness of current global challenges must be investigated in further research.

\section{Conclusions}

Mental maps, graphic-cartographic representations of the subjective ideas of a spatial situation, are created from individually selected elements of spatial reality. As a rule, they do not correspond to the real conditions. As can be seen from the pilot study, the use of additional materials, images, world maps or globes clearly influences the features of these mental maps. Targeted guiding questions make it possible to find out the sources of the contents of the cognitive maps that go beyond spatial perception. These specific patterns of perception and access to the content from the extended world of children show how problems and challenges from the global world are integrated into children's subjective ideas. The pupils' work with Mental Maps helps them to classify their perceptions, establish global connections and develop a readiness for futureoriented action. "Self-efficacy manifests itself as basic competence by critical, structuring, dispositive thinking as well as co-operative and creative approaches in the problemsolving process" (Lindner, 2015; Salite, 2015; Fedosejeva et al., 2018).

The analysis of these individual and specific views of children in elementary school enables a targeted approach to teaching. Here, entrepreneurship education which already begins at the primary level, can stimulate or strengthen development processes. 


\section{References}

Adamina, M. (2014). Geographisches Lernen und Lehren [Teaching and learning geography]. In Hartinger, A., \& Lange, K. (Eds.), Sachunterricht - Didaktik für die Grundschule [Didactics of social and science studies in primary education] (pp. 79-98). Berlin: Cornelsen.

Behrendt, H., \& Reiska, P. (2001). Abwechslung im Naturwissenschaftsunterricht mit Concept Mapping [Variety of science studies with concept mapping]. Retrieved from http://pluslucis.univie.ac.at/PlusLucis/011/s0912.pdf

Bönsch, M. (2012). Mind Mapping im Sachunterricht. Visualisieren - Strukturieren Präsentieren [Mind mapping in social and science studies. Visualize - Structure Presentation]. In Kaiser, A., \& Pech, D. (Eds). (2012). Basiswissen Sachunterricht. Unterrichtsplanung und Methoden [Basic knowledge in social and science studies. Lesson planning and methods]. Baltmannsweiler: Schneider V. Hohengehren.

Bundeskanzleramt: Nachbaltige Entwicklung - Agenda 2013/SDGs [Federal chancellery: Sustainable development-agenda 2013/SDGs]. Retrieved from https://www. bundeskanzleramt.gv.at/nachhaltige-entwicklung-agenda-2030 [Austrian Strategy for Sustainable Development].

Curriculum für das Bachelorstudium für Primarstufe der KPH Wien/Krems [Curriculum for the bachelor's degree for the primary level at KPH Vienna/Krems]. Retrieved from https://www.kphvie.ac.at/fileadmin/Mitteilungsblatt/KPH-2019_MB_ 169_Bachelor_Gesamt_19_06_24.pdf

Dangschat, J. S., \& Kogler, R. (2019). Qualitative räumliche Daten [Qualitative spatial data]. In Baur, N., \& Blasius, J. (Eds.), Handbuch Methoden empirischer Sozialforschung [Manual for methods of social research]. (pp. 1337-1344). Wiesbaden, Springer.

Fedosejeva, J., Boče, A., Romanova, M., Iliško, Dz., \& Ivanova, O. (2018). Education for sustainable development: The choice of pedagogical approaches and methods for the implementation of pedagogical tasks in the Anthropocene age. Journal of Teacher Education for Sustainability, 20(1), 157-179. Retrieved from https://doi.org/10.2478/jtes2018-0010

Gryl, I. (2010). Mündigkeit durch Reflexion. Überlegungen zu einer multiperspektivischen Kartenarbeit [Autonomy through reflection. Strategic review of multiperspective map work]. GW-UNTERRICHT [Journal for Geography and Economic Instruction], 118, 20-37.

Mayring, P. (2010). Qualitative Inhaltsanalyse: Grundlagen und Techniken [Qualitative content analyses. Basics and technics]. Weinheim: Beltz.

Kaminske, V. (2012). Die räumliche Wahrnehmung. - Grundlagen für Geographie und Kartographie [Spatial perception. - Basics of geography and cartography]. Darmstadt, 12.

Kaminske, V. (2013). Mental Map-Repräsentation der Lernlandschaft [Mental map presentations of learning landscape]. Geographie und Schule [Geography and Education], 5 .

Kestler, F. (2002). Einführung in die Didaktik des Geographieunterrichts [Introduction to the didactics of geography] (p. 107). Riedem: Klinkhardt.

Lenz, T. (2006). Topographische und kartographische Bildung [Topographic and cartographic education]. In Haubrich, H. (Ed.), Geographie unterrichten lernen. 
Die neue Didaktik der Geographie konkret [Learning geography education. The new specific didactics of geography]. München: Oldenburg.

Lindner, J. (2015). Entrepreneurship Education für Jugendliche [Entrepreneurship education for young people], 40. Retrieved from www.gw-unterricht.at

Montessori, M. (1997). Kosmische Erziehung [Cosmic education]. Kleine Schriften. Freiburg: Herder.

Pröbstl, G., \& Schmidt-Hönig, K. (2020). Self-efficacy in social science. Discourse and Communication for Sustainable Education, 10(2), 49-59. doi: 10.2478/dcse-20190017

Ribero, St. (2013). Wie weit ist es dahin? Längen, Strecken, Wege - Grundschüler untersuchen Entfernungen [How far is it? Lengths, distances, routes - Primary school pupils discover distances]. Grundschulmagazin [Journal for Primary Education], (3), 22-24.

Salite, I. (2015). Searching for sustainability in teacher education and educational research: Experiences from the Baltic and Black Sea Circle Consortium for educational research. Discourse and Communication for Sustainable Education, 6(1), 21-29.

Schäfer, G. (1984). Die Entwicklung des geografischen Raumverständnisses im Grundschulalter. Ein Beitrag zur Curriculumdiskussion [Development of spatial understanding at primary school age. Input to a debate about the curriculum]. Berlin: Dietrich Reimer Verlag.

Schmeinck, D. (2007). Wie Kinder die Welt sehen. Eine empirische Ländervergleichsstudie zur räumlichen Vorstellung von Grundschulkindern [The world in children's view. An empiric study in various countries to the spatial understanding of primary school pupils]. Bad Heilbrunn: Verlag Julius Klinkhardt.

Schmeinck, D. (2013). Elementare geografische Bildung in der Grundschule. Herausforderungen für den Sachunterricht [Basic education in geography for primary school]. Grundschulmagazin [Journal for Primary School], 3, 7-10. Retrieved from www.grundschulmagazin.de

Schniotalle, M. (2003). Räumliche Schülervorstellungen von Europa. Ein Unterrichtsexperiment zur Bedeutung kartografischer Medien für den Aufbau räumlicher Orientierung im Sachunterricht der Grundschule [Primary school pupils' spatial understanding of Europe. A teaching experiment on the importance of cartographic media for the development of spatial orientation in subject teaching in primary schools]. Berlin: Tenea Verlag.

Schniotalle, M. (2015). Die weite Welt als Mental Map [The world as a mental map]. Grundschule [Journal for Primary School], 11.

Schwarz, I. (2010). Globales Lernen und das Konzept der Orte und Nicht-Orte [Global learning and the concept of place and non-place]. In Schrüfer, G., \& Schwarz, I. (Eds.), Globales Lernen [Global learning] (pp. 11-25). Ein geographischer Diskursbeitrag. Münster: Waxmann.

Stoltenberg, U. (2013). (Ed.). Weltorientierung durch Bildung für eine nachhaltige Entwicklung: Theoretische Grundlagen und Praxis des Sachunterrichts in der Grundschule [World orientation through education for a sustainable development: Theoretical foundations and practice of subject teaching in the primary school]. Bad Homburg: VAS.

United Nations. Sustainable Development Goals. Retrieved from https://en.unesco.org/ sites/default/files/styles/extra_large_1600x1600/public/sdgs_poster_936_en. png? itok=KNGaZ2c4 
Vielhaber, C. (2000). Geschichten von Lebenswelten und Weltbildern [Stories of lifeworlds and world views]. Tragfähige Erschließungsperspektiven für eine kritische Geographiedidaktik? [Journal for Geography and Economic Instruction], 77, 4451.

Weichhart, P. (2008). Entwicklungslinien der Sozialgeographie [Trends of social geography]. Von Hans Bobek bis Benno Werlen. Stuttgart: Steiner Verlag.

Weixelbaumer, N. (2001). Wahrnehmungsgeographie [Perceptual geography]. In Sitte, W. (Ed.), Beiträge zur Didaktik des "Geographie-und WirtschaftskundeUnterrichts”. Institut für Geographie- und Regionalforschung der Universität Wien [Contributions to the didactics of "geography and economics lessons" (pp. 518530). Institute for Geography and Regional Research at the University of Vienna]. Ziervogel, D. (2011). Mental-Map-Methoden in der Quartierforschung. Wahrnehmung, kognitive Repräsentation und Verhalten im Raum [Mental map methods for district research. Perception, cognitive representation and behavior in space]. In Frey, O., \& Koch, F. (Eds.), Positionen zur Urbanistik I. [Positions on urbanistics I] (pp. 187206). Stadtkultur und neue Methoden der Stadtforschung. Wien: LIT-Verlag.

Correspondence relating this paper should be addressed to Kerstin Schmidt-Hönig, The University College of Teacher Education Vienna/Krems. Email: kerstin.schmidthoenig@kphvie.ac.at

or

to Gerlinde Pröbstl, The University College of Teacher Education Vienna/Krems; University of Vienna, Department of Geography and Regional Research. Email: gerlinde.proebstl@kphvie.ac.at 